\title{
Insulin-like growth factor (IGF) system in the oocyte and somatic cells of bovine preantral follicles
}

\author{
D. G. Armstrong, G. Baxter, C. O. Hogg and K. J. Woad \\ Department of Integrative Biology, Roslin Institute, Roslin, Midlothian EH25 9PS, UK
}

\begin{abstract}
Many studies have highlighted the role of the insulin-like growth factor (IGF) system in the control of antral follicular growth. However, much less is known about the involvement of the IGF system in the regulation of preantral follicular development. In an attempt to address this lack of knowledge, the present study describes the spatial and temporal patterns of expression of mRNA encoding components of the IGF system in bovine follicles during preantral stages of development. mRNA was detected by in situ hybridization using frozen sections $(14 \mu \mathrm{m})$ of bovine ovarian tissue. Serial sections were probed with ${ }^{35}$ S-labelled bovine riboprobes. Type 1 IGF receptor mRNA was detected in granulosa cells and in the oocyte of preantral follicles; however, in this study, as in previous studies, it was not possible to detect mRNA
\end{abstract}

encoding either IGF-I or -II. IGF binding protein (IGFBP)-2 mRNA was present in granulosa cells and oocytes of preantral follicles, and immunoreactive IGFBP-2 was detected around granulosa cells during this early stage of development. Occasionally, preantral follicles were identified in which there was no expression of IGFBP-2 in granulosa cells or the oocyte. IGFBP-3 mRNA was detected in the oocyte of preantral follicles and in the surrounding stromal tissue. mRNAs encoding IGFBP-2 and -3 , and type 1 IGF receptor were first detected in type 2 follicles. In conclusion, although the IGF ligands are not expressed in preantral follicles, mRNAs encoding the type 1 IGF receptor, and IGFBP-2 and -3 were present and showed unique spatial patterns of expression within preantral follicles.

\section{Introduction}

The insulin-like growth factor (IGF) system is an essential component of the intraovarian mechanisms involved in the regulation of follicle growth and corpus luteum function (Giudice, 1992; Armstrong and Webb, 1997; Armstrong et al., 1998; Woad et al., 2000). The role of this system in controlling follicle growth has been deduced primarily from experiments using primary cultures of granulosa and theca cells isolated from antral follicles (Adashi et al., 1994; Campbell et al., 1996; Gutierrez et al., 1997). The principal conclusion from such experiments is that IGFs interact synergistically with $\mathrm{FSH}$ and $\mathrm{LH}$ to regulate proliferation and differentiation of granulosa and theca cells.

These in vitro studies have been complimented by investigations describing the spatial expression of mRNAs encoding components of the IGF system in antral follicles from a number of mammalian species. For example, in cattle, Armstrong et al. (2000) demonstrated that mRNA encoding type 1 IGF receptor is present in both theca and granulosa cells and that IGF-II, the principal intrafollicular IGF ligand in ruminants, is produced only by thecal tissue. IGF binding protein (IGFBP)-2 and -4 are produced by granulosa and theca tissue of antral follicles, respectively, and they regulate the bioavailability of intrafollicular IGF

Email: david.armstrong@bbsrc.ac.uk during follicular development (Armstrong et al., 1998, 2001). Comparison between species has indicated a significant difference within the ovarian IGF system with regards to the specific components of the IGF system that are expressed, as well as in the spatial distribution of IGF expression within antral follicles (Armstrong and Webb, 1997; Webb et al., 1999). For example, in polyovulating species, such as pigs and rodents, granulosa IGF-I production prevails, whereas in mono-ovulators, such as ruminants and humans, thecal-derived IGF-II is the major intrafollicular ligand.

The importance of IGFs in the regulation of ovarian function in mice has been confirmed by gene knockout experiments (Baker et al., 1996; Zhou et al., 1997; Elvin and Matzuk, 1998) that have shown that IGF-I is required for antral follicle development. However, the precise interpretation of such results is complicated by functional redundancy within the IGF system and caution should be exercised when extrapolating results obtained in mice to other species because of differences in their follicular IGF system. In this regard, it has been shown that, even between two closely related species, such as rats and mice, there are significant differences in the spatial patterns of expression of IGFBP-2 and -4 within antral follicles (Adashi et al., 1997).

In contrast to the later stages of follicle growth, little is known about the IGF system during preantral follicle development. However, recent studies have shown that 

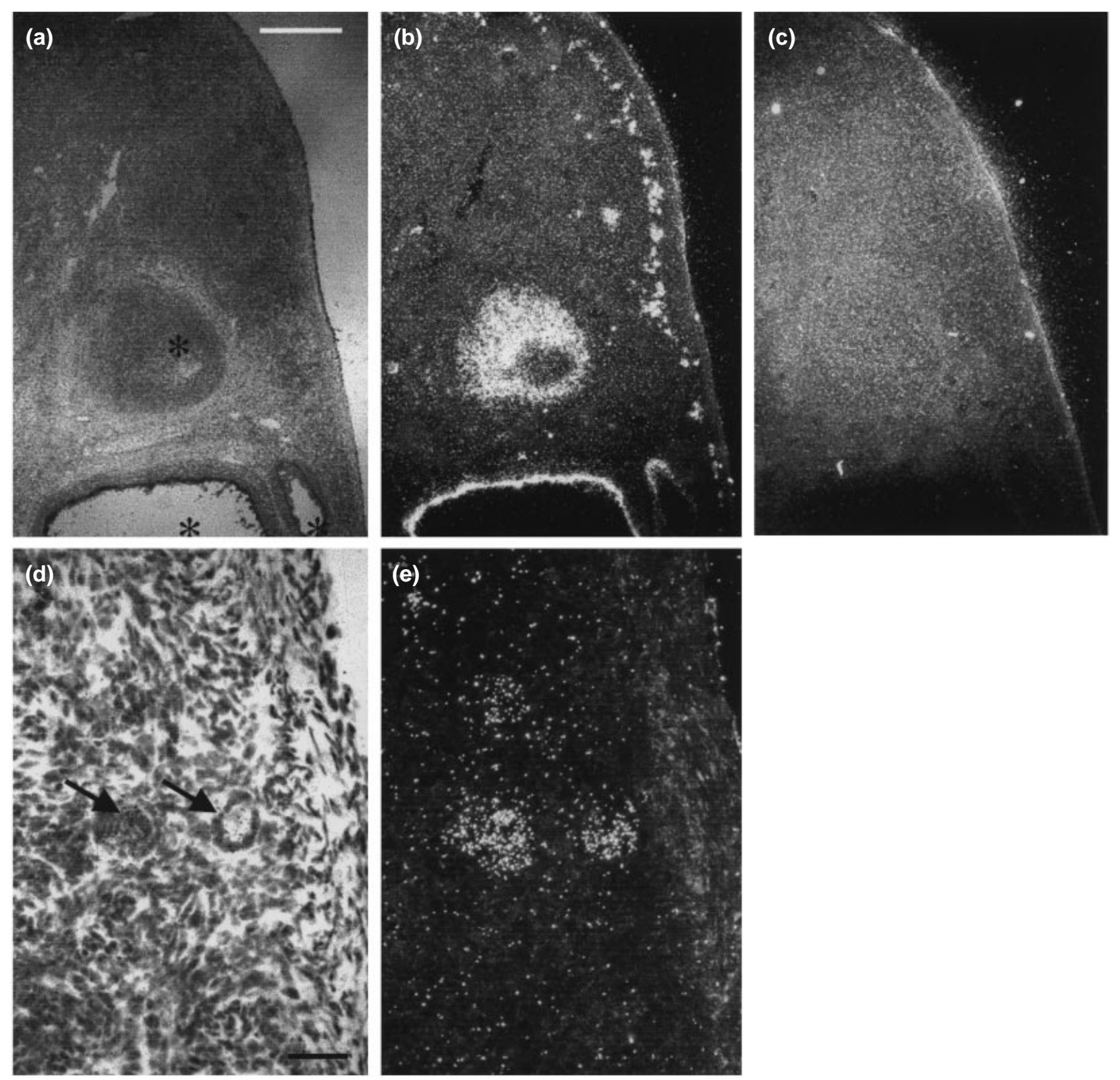

Fig. 1. Light field $(a, d)$ and dark field (b,c,e) illumination of frozen sections of bovine ovarian tissue $(14 \mu \mathrm{m})$ probed with antisense $(a, b, d, e)$ and sense (c) insulin-like growth factor binding protein (IGFBP)-2 RNA viewed under low (a,b,c) and medium (d,e) magnification. A string of preantral follicles containing silver grains is observed in the ovarian cortex under dark field illumination and low magnification. Asterisks indicate antral follicles. Solid arrows indicate primary follicles with oocytes containing silver grains. Scale bars represent 400 and $60 \mu \mathrm{m}$ in the low $(\mathrm{a}, \mathrm{b}, \mathrm{c})$ and high $(\mathrm{d}, \mathrm{e})$ magnification images, respectively.

both the growth and ultrastructure of preantral follicles are regulated in vitro by IGFs (Gutierrez et al., 2000; McCaffery et al., 2000; Louhio et al., 2000; Zhao et al., 2001). It is necessary to understand the role of the IGF system in controlling preantral follicle growth and how this system interacts with other locally produced growth factors so that physiologically relevant culture systems can be developed for bovine follicles during the early stages of development.
The present study was designed to increase understanding of the role of the IGF system in the regulation of preantral follicle growth and oocyte maturation in a mono-ovulating species. The specific aims were to describe the spatial pattern of expression of mRNA encoding the components of the IGF system within bovine preantral follicles and to define the stage of preantral follicle development at which these components are first detected. 

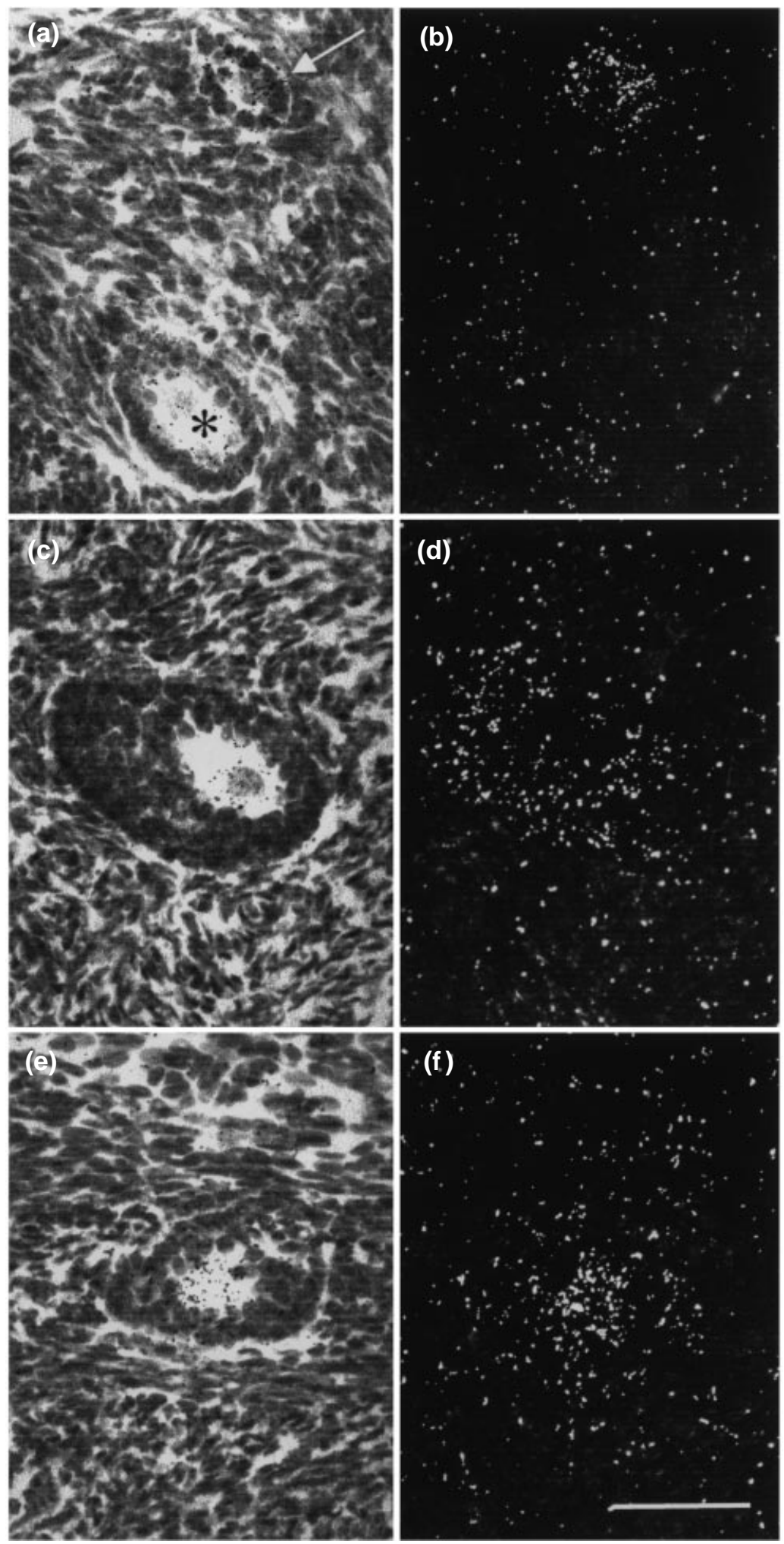

Fig. 2. Light field $(a, c, e)$ and dark field $(b, d, f)$ illumination of frozen sections of bovine ovarian tissue $(14 \mu \mathrm{m})$ probed with antisense insulin-like growth factor binding protein (IGFBP)-2 RNA. Two adjacent preantral follicles are shown: one in which IGFBP-2 mRNA is expressed (indicated by the arrow) and the other in which IGFBP-2 mRNA is not expressed (indicated by the asterisk). Scale bar represents $60 \mu \mathrm{m}$. 

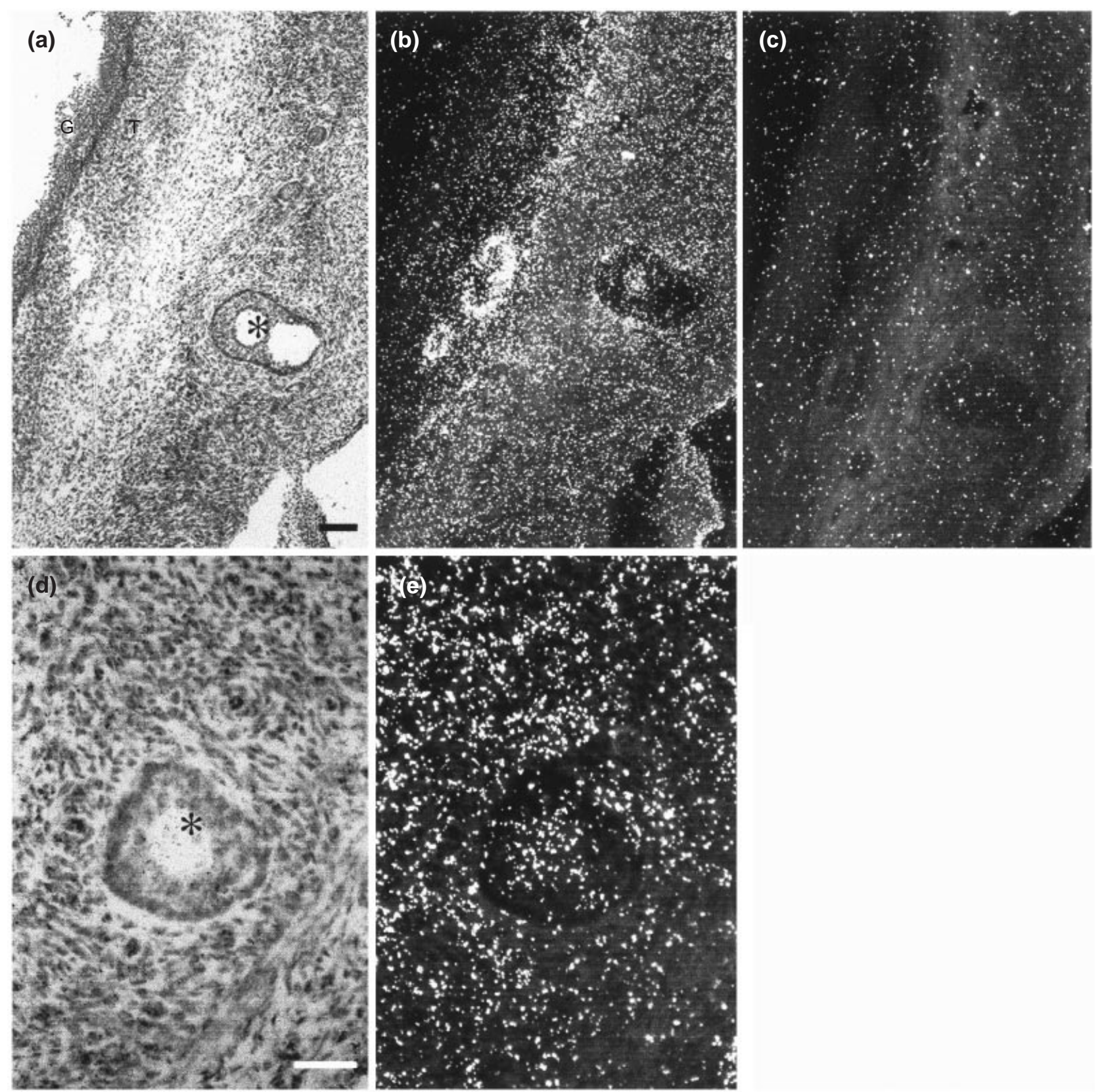

Fig. 3. Light field $(a, d)$ and dark field (b,c,e) illumination of frozen sections of bovine ovarian tissue (14 $\mu \mathrm{m})$ probed with antisense $(a, b, d, e)$ and sense (c) insulin-like growth factor binding protein (IGFBP)-3 RNA viewed under low (a,b,c) and medium (d,e) magnification. Silver grains are observed in an oocyte (indicated by asterisks) in an antral and primary follicle and throughout the ovarian stroma. Granulosa (G) and theca (T) tissue in a large preantral follicle. Scale bars represent 100 and $50 \mu \mathrm{m}$ in the low (a,b,c) and high $(\mathrm{d}, \mathrm{e})$ magnification images, respectively.

\section{Materials and Methods}

\section{Tissue collection and experimental design}

Ovaries $(n=6)$ were obtained from six cows at the local abattoir. The ovaries were immediately divided into blocks, snap frozen in liquid nitrogen and stored at $-70^{\circ} \mathrm{C}$. Serial sections $(14 \mu \mathrm{m})$ were cut through the ovarian cortex and stored in sealed boxes at $-70^{\circ} \mathrm{C}$ in the presence of a desiccant until required. In total, 240 sections were cut (20 sections per block and two blocks for each of six ovaries). Two serial sections were analysed with each antisense riboprobe and the subsequent serial sections were analysed with the corresponding sense probe. For each probe and antibody, 36 sections were analysed (two sets of three serial sections from six cows). 

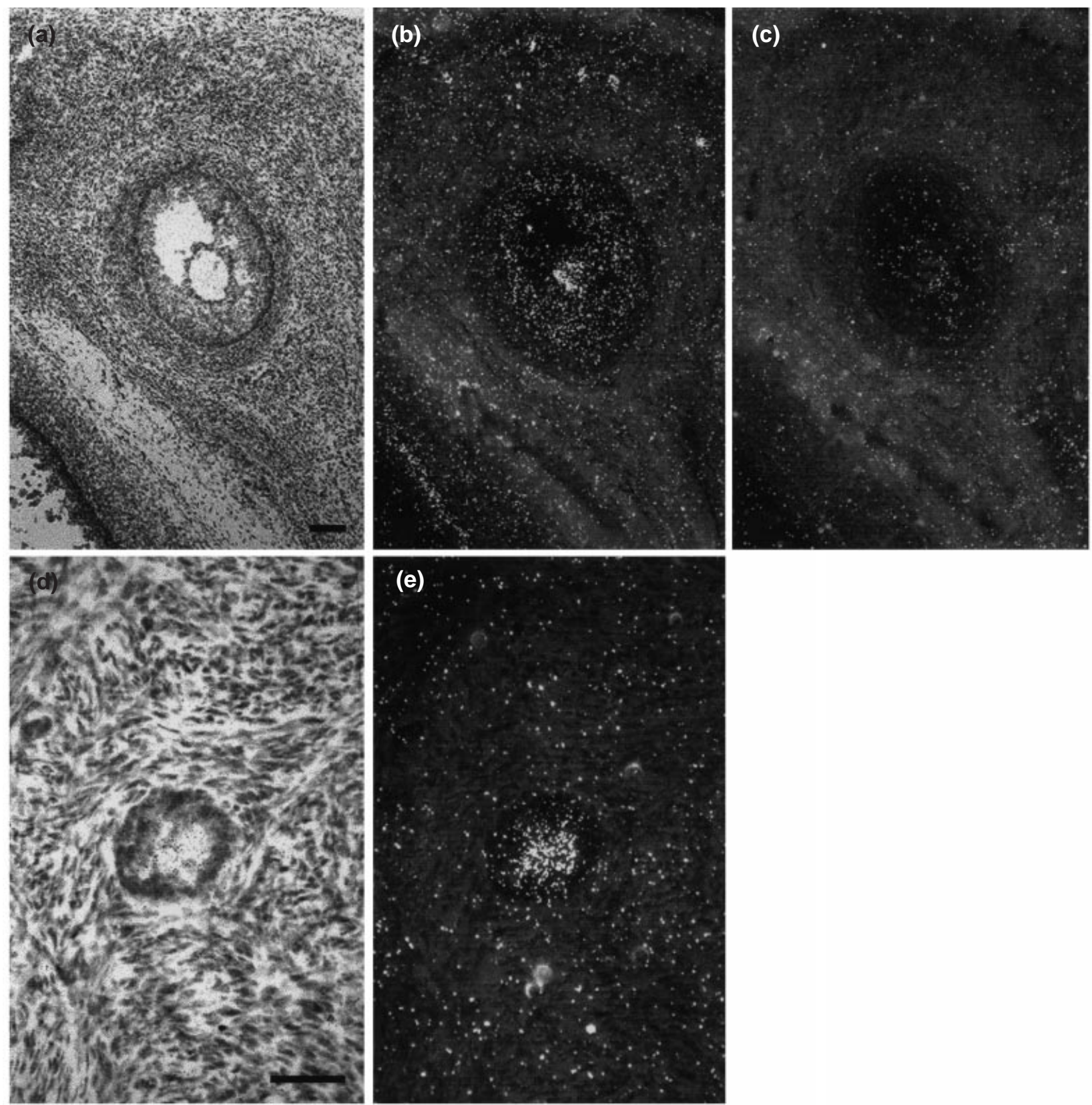

Fig. 4. Light field $(a, d)$ and dark field (b,c,e) illumination of frozen sections of bovine ovarian tissue $(14 \mu \mathrm{m})$ probed with antisense (a,b,d,e) and sense (c) type 1 insulin-like growth factor (IGF) receptor RNA viewed under low (a,b,c) and medium (d,e) magnification. Scale bars represent 100 and $50 \mu \mathrm{m}$ in the low $(\mathrm{a}, \mathrm{b}, \mathrm{c})$ and high $(\mathrm{d}, \mathrm{e})$ magnification images, respectively.

\section{RNA probes}

${ }^{35}$ S-labelled bovine riboprobes used for the detection of mRNA encoding IGF-I and -II, IGFBP-2 and type 1 IGF receptor were as described in studies by Armstrong et al. (1998, 2000). The IGFBP-3 probe was prepared by reverse transcriptase (Armstrong et al., 1998) using RNA isolated from bovine corpora lutea (Woad et al., 2000). The cDNA was amplified using a 21-mer upstream primer (5'-ATTCCACCCCATCCACACCAA-3') and downstream primer (5'-CACGTCCCCTTTCCCCTTCAC-3'). The amplified product (358 base pairs) corresponded to position 611-968 of a bovine IGFBP-3 cDNA (Spratt et al., 1991) and was cloned into pGEM-T (Promega). Antisense and sense RNA probes were transcribed from linearized cDNA templates following a standard transcription protocol (Promega). The RNA probes were labelled with $\left.{ }^{35} \mathrm{~S}\right]$-UTP (Amersham Pharmacia Biotech UK Ltd, Little Chalfont, Bucks). In RNase protection assays, all probes produced RNase resistant fragments of RNA of the expected size (Woad, 2001). 

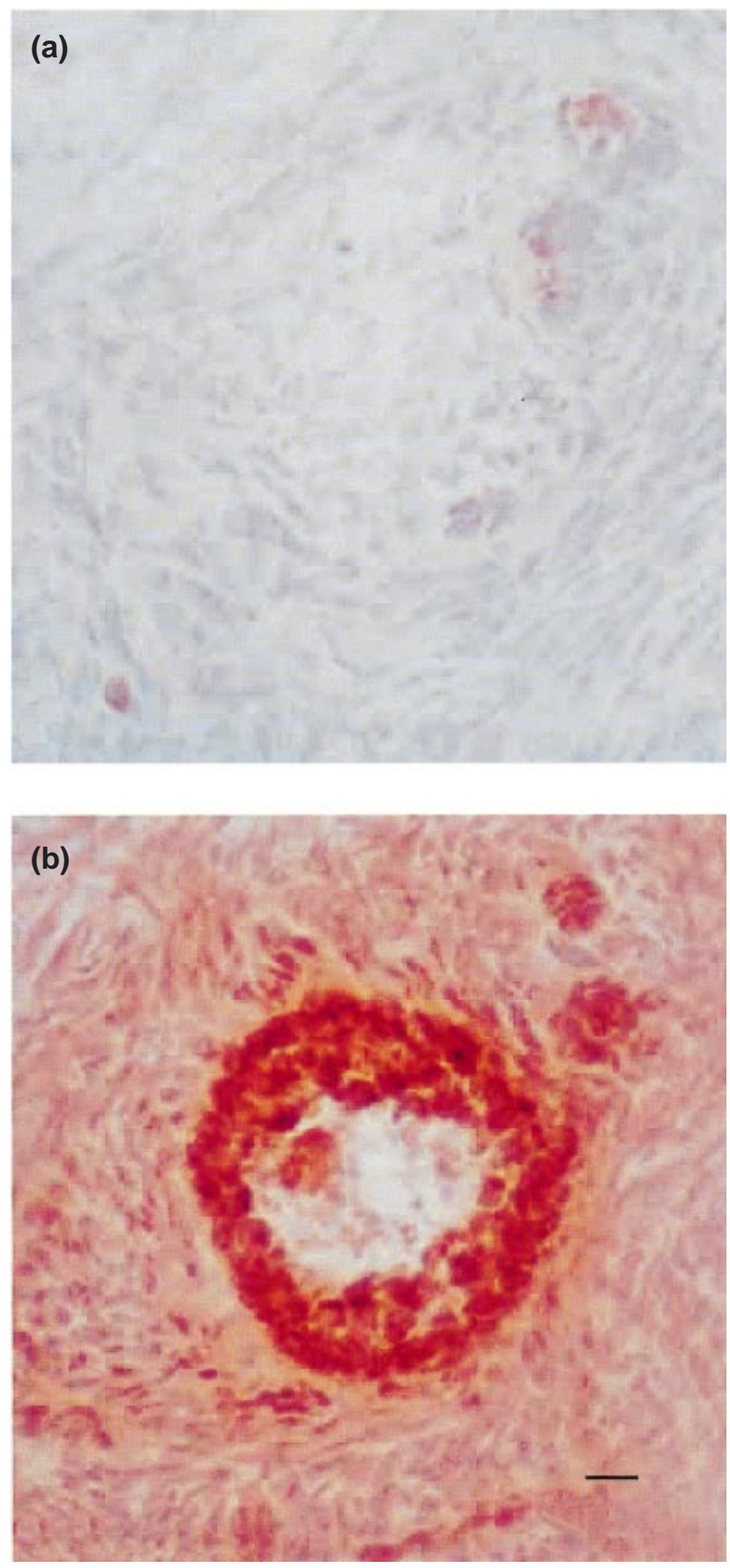

Fig. 5. Bovine ovarian sections incubated with (a) normal rabbit serum or (b) an antibody raised against bovine recombinant insulin-like growth factor binding protein (IGFBP)-2. Scale bar represents $25 \mu \mathrm{m}$.

\section{In situ hybridization}

Details of the procedure used have been described by Armstrong et al. (1998, 2000). Briefly, frozen sections $(14 \mu \mathrm{m})$ were allowed to warm up to room temperature; they were dehydrated, fixed and probed with ${ }^{35}$ S-labelled riboprobes (Armstrong et al., 1998). After the final high stringency wash, the sections were dipped in autoradiographic K2 photographic emulsion (Ilford Limited, Mobberley, Cheshire) and exposed for 3 weeks at $4^{\circ} \mathrm{C}$. Sections were developed (Kodak D-19) and fixed (Ilford Hypam fixer) before staining in haematoxylin and eosin. The sections were finally mounted in DPX mountant (R. A. Lamb, Sunbeam Road, London) before microscopic examination using both light and dark field illumination.

\section{Immunohistochemistry}

Immunohistochemistry was carried out as described by Armstrong et al. (1998). The rabbit anti-bovine IGFBP-2 antiserum (Upstate Biotechnology Incorporated, Lake Placid, NY) was diluted 1:500 before use. After probing with primary antibody, the sections were washed and stained using a goat anti-rabbit IgG labelled with horseradish peroxidase (Dako Laboratories, Ely). Nonspecific binding was detected by replacing primary antibody with normal rabbit serum.

\section{Results}

\section{Expression of IGFBP-2 mRNA}

mRNA encoding IGFBP-2 was detected in frozen sections of bovine ovarian tissue (Fig. 1). In addition to its localization in granulosa tissue of antral follicles (Fig. 1a), mRNA encoding IGFBP-2 was also located in granulosa cells and the oocyte of preantral follicles. mRNA encoding IGFBP-2 is highlighted in two primary follicles (Fig. 1d). The expression between follicles varied. Two adjacent follicles were identified (Fig. 2a): IGFBP-2 mRNA was expressed in one follicle but not in the other. Preantral follicles were also detected in which IGFBP-2 mRNA was expressed only in the granulosa cells (Fig. 2c,d) or oocytes (Fig. 2e,f)

\section{Expression of IGFBP-3 $m R N A$}

mRNA encoding IGFBP-3 was not detected in granulosa cells from either preantral or antral follicles (Fig. 3). IGFBP-3 expression was detected in oocytes from antral and preantral follicles (Fig. 3b,e). In addition, IGFBP-3 mRNA was detected in the theca externa of antral follicles. Of particular interest was the detection of IGFBP-3 mRNA in stromal tissue surrounding preantral follicles. High expression was also detected in blood vessels, two of which are near the antral follicle shown (Fig. 3b).

\section{Expression of type 1 IGF receptor $m R N A$}

mRNA encoding type 1 IGF receptor was detected in the oocyte and granulosa cells of an antral follicle (Fig. 4b). A preantral follicle is shown under higher magnification (Fig. $4 d, e)$ and a large number of silver grains are associated with the oocyte. 


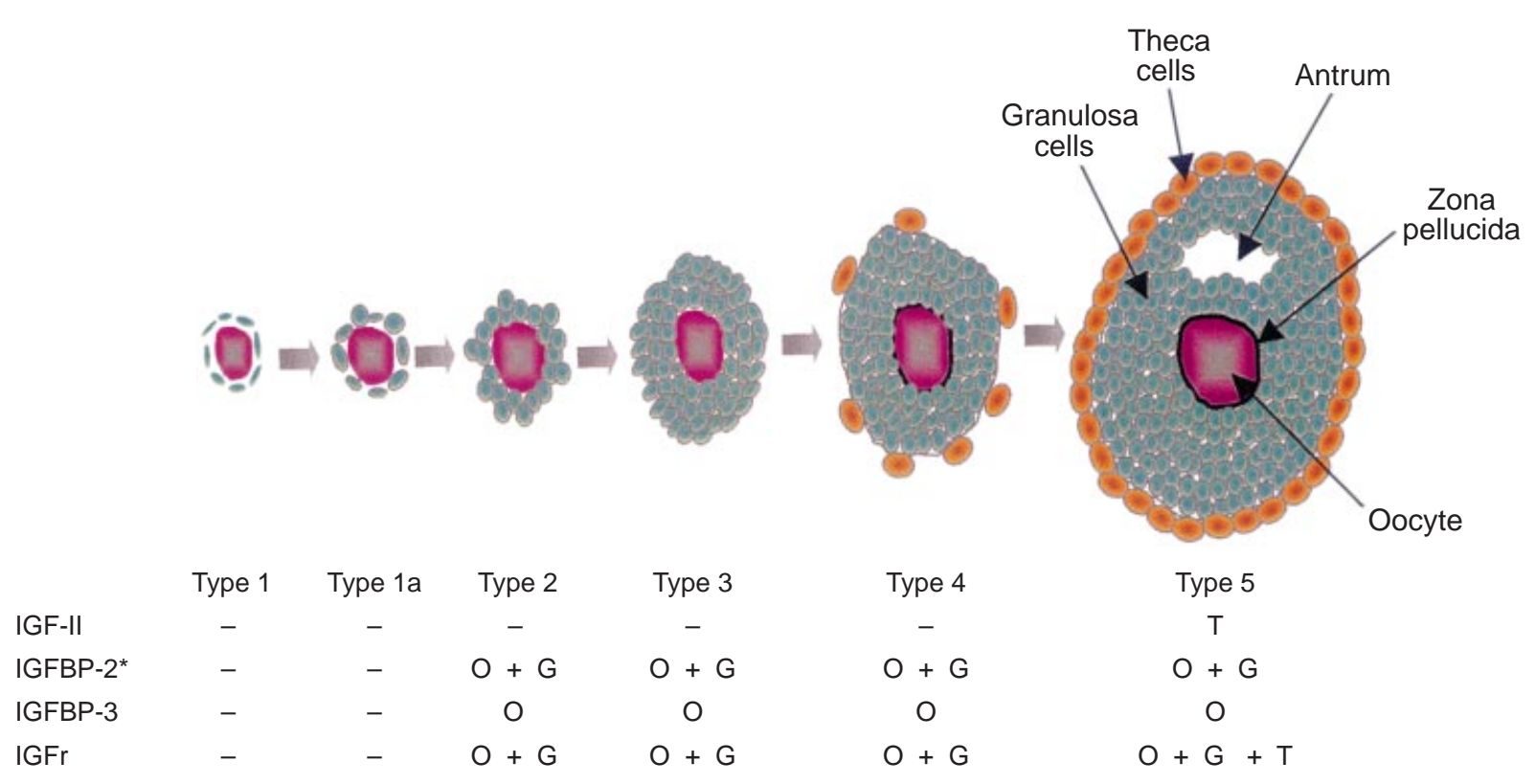

Fig. 6. Diagrammatic representation of the temporal changes in the expression of mRNA encoding components of the insulinlike growth factor (IGF) system in bovine follicles during the transition from type 1 to type 5 growth stages (Braw-Tal and Yossefi, 1997). IGFr represents type 1 IGF receptor. O: oocyte, G: granulosa cells; T: theca cells. *Preantral follicles were also identified that did not contain mRNA encoding IGFBP-2 in granulosa cells and/or oocytes of preantral follicles.

\section{Expression of IGF-I and -II $m R N A$}

mRNA encoding IGF-I and -II was not detected in preantral follicles at any stage of preantral follicle development.

\section{Localization of IGFBP-2 immunoactivity in preantral follicles}

IGFBP-2 immunoactivity (Fig. 5) was localized within the granulosa cell layer of preantral follicles.

\section{Developmental changes in the expression of $m R N A$ encoding components of the IGF system during early follicle growth}

The pattern of expression of components of the IGF system is shown (Fig. 6). Expression of IGFBP-2 (granulosa cells and oocyte), IGFBP-3 (oocyte) and type 1 IGF receptor (granulosa cells and oocyte) mRNA was first detected in bovine follicles containing more than one layer of granulosa cells. In contrast, mRNA encoding IGF-II was first detected in thecal tissue at the time of antrum formation.

\section{Discussion}

The present study demonstrates that granulosa cells of preantral follicles express mRNAs encoding IGFBP-2 and type 1 IGF receptor. Oocytes from these preantral follicles also express mRNAs encoding IGFBP-2 and -3, and type 1 IGF receptor. Unlike pig granulosa cells that express mRNA encoding IGFBP-3 (Wandji et al., 2000), bovine granulosa cells do not express IGFBP-3. However, the theca externa of antral follicles and the stromal tissue surrounding preantral follicles were shown to be sites of IGFBP-3 mRNA expression. Armstrong et al. (2000) indicated that IGF-II mRNA was first detected in thecal tissue at about the time of antrum formation and that IGF-I and -II mRNA was not expressed in granulosa cells of preantral or antral follicles. It was hypothesized that IGFs regulate preantral follicle growth via endocrine mechanisms. The results presented here support this observation and we hypothesize that IGFBP-2 and -3 regulate the bioavailability of IGF-I (derived from the circulation) and IGF-II (derived from adjacent antral follicles) during early follicular growth.

In cattle, the primordial follicles consist of an oocyte surrounded by approximately 24 flattened or cuboidal granulosa cells (van Wezel and Rodgers, 1996). Mechanisms that regulate the activation and subsequent growth of these follicles remain poorly understood. Early follicular growth can be divided into two distinct phases (Braw-Tal and Yossefi, 1997). The first phase involves the transition of the granulosa cells surrounding the oocyte from a phenotype consisting of a mixture of flattened and cuboidal shapes (type 1 and 1a follicles) to a cuboidal proliferating phenotype (type 2 follicle) and occurs without a significant change in oocyte diameter. Bovine type 2 follicles contain up to 40 cuboidal granulosa cells arranged as two layers around the oocyte and the second phase of growth is characterized by proliferation of these granulosa cells and a rapid increase in the size of the oocyte. In cattle, the critical point for the initiation of oocyte growth was estimated by Braw-Tal and Yossefi (1997) to occur in 
follicles containing approximately 40 granulosa cells. At this stage, the bovine oocyte has yet to develop a complete zona pellucida and it will double in diameter during the transition from type 2 to type 4 growth stages. As mRNAs encoding IGFBP-2 and -3 and type 1 IGF receptor were first detected in type 2 follicles, the expression of components of the IGF system can be correlated with the onset of the second phase of early follicle growth.

Although the use of transgenic mice has allowed the effects of growth factor gene ablation and overexpression on preantral follicle growth to be determined, the precise role of many of these factors during early follicle growth in ruminants relies on the development of physiologically relevant follicle culture systems. This has relevance to the interpretation of results obtained using IGF-I knockout mice (Baker et al., 1996). Histological examination of the ovaries of knockout mice showed that they contained follicles from the primordial up to the early antral stage of development and rarely contained preovulatory Graafian follicles. It was concluded that IGF-I was not necessary for preantral follicle growth. However, it is possible that insulin or IGF-II acting through the type 1 receptor can compensate for the loss of IGF-I in the null mutant mice, thus allowing growth of preantral follicles.

Early attempts at developing serum-free bovine culture systems that support activation and subsequent growth of primordial follicles made use of explants of ovarian cortex (Wandji et al., 1996; Fortune et al., 2000). In this system, primordial follicle growth was initiated as indicated by a decrease in the number of primordial follicles and a concomitant increase in the number of primary follicles. In contrast to rodents in which this system resulted in normal rates of primordial follicle activation, in cattle it resulted in uncontrolled activation. The reasons for these differences are unknown. Although IGFs were not added to the medium used to support follicle development, supra-physiological concentrations of insulin were used, which have the potential to act via the IGF receptors at these high concentrations. This observation is potentially important, as in the present study it was demonstrated that preantral follicles express both IGFBP-2 and -3, which would be expected to bind IGFs and so limit their access to the type 1 receptor. Thus, the use of high concentrations of insulin in vitro could bypass mechanisms that regulate activation of the type 1 IGF receptor in vivo. Zhoa et al. (2001) reported that IGF-I stimulated preantral follicle growth even in the presence of supra-physiological concentrations of insulin. Nevertheless, differential effects of IGF-I and an IGF analogue that did not bind to IGFBPs on preantral follicle growth and oocyte size have been demonstrated (McCaffery et al., 2000, 2001). It was also demonstrated that increased intrafollicular IGF bioavailability, arising from nutritionally induced changes in the expression of mRNA encoding IGFBP-2 in small antral follicles, is correlated with reduced oocyte developmental competence (Armstrong et al., 2001). In addition, the growth of preantral follicles, but not of the oocyte, was stimulated by IGF-I in long-term cultures of individual bovine preantral follicles that promoted the formation of an antrum (Gutierrez et al., 2000).

In conclusion, the results from the present study indicate that although expression of IGF receptors was detected in bovine preantral follicles, there was no intrafollicular production of IGF ligands during this stage of development. The spatial and temporal pattern of expression of the components of the IGF system during the early stages of bovine follicular growth are summarized (Fig. 6). The results indicate that the IGF system is not involved in the initiation of primordial follicle growth but is involved in subsequent events. It is hypothesized that IGFBP-2 and -3 in preantral follicles will bind any IGF arriving from the circulation or adjacent antral follicles and regulate its access to the type 1 IGF receptors in the oocyte and granulosa cells of preantral follicles.

This work was supported by a BBSRC core strategic grant.

\section{References}

Adashi EY (1994) Growth factors and ovarian function: the IGF-I paradigm Hormone Research 42 44-48

Adashi EY, Resnick CE, Payne DW, Rosenfeld RG, Matsumoto T, Hunter MK, Gargosky SE, Zhou J and Bondy CA (1997) The mouse intraovarian insulin-like growth factor I system: departures from the rat paradigm Endocrinology 138 3881-3890

Armstrong DG and Webb R (1997) Ovarian follicular dominance: the role of intraovarian growth factors and novel proteins Reviews of Reproduction 2 139-146

Armstrong DG, Baxter G, Gutierrez CG, Hogg CO, Glazyrin AL, Campbell BK, Bramley TA and Webb R (1998) Insulin-like growth factor binding protein-2 and -4 mRNA expression in bovine ovarian follicles: effect of gonadotropins and developmental status Endocrinology 139 2146-2154

Armstrong DG, Gutierrez CG, Baxter G, Glazyrin AL, Mann GE, Woad KJ, Hogg CO and Webb R (2000) Expression of mRNA encoding IGF-I, IGFII and type 1 IGF receptor in bovine ovarian follicles Journal of Endocrinology 165 101-113

Armstrong DG, McEvoy TG, Baxter G, Robinson JJ, Hogg CO, Woad KJ and Webb R (2001) Effect of dietary energy and protein on bovine follicular dynamics and embryo production in vitro: associations with the ovarian insulin-like growth factor system Biology of Reproduction 64 1624-1632

Baker J, Hardy MP, Zhou J, Bondy C, Lupu F, Bellve AR and Efstatiadis A (1996) Effects of IGF1 gene null mutation on mouse reproduction Molecular Endocrinology 10 903-918

Braw-Tal R and Yossefi S (1997) Studies in vivo and in vitro on the initiation of follicle growth in the bovine ovary Journal of Reproduction and Fertility 109 165-171

Campbell BK, Scaramuzzi RJ and Webb R (1996) Induction and maintenance of oestradiol and immunoreactive inhibin production with FSH by ovine granulosa cells cultured in serum free media Journal of Reproduction and Fertility 106 7-16

Elvin JA and Matzuk MM (1998) Mouse models of ovarian failure Reviews of Reproduction 3 183-195

Fortune JE, Cushman RA, Wahl CM and Kito WS (2000) The primordial to primary follicle transition Molecular and Cellular Endocrinology 163 53-60

Giudice LC (1992) Insulin-like growth factors and ovarian development Endocrine Reviews 13 641-669

Gutierrez CG, Campbell BK and Webb R (1997) Development of a longterm bovine granulosa cell culture system: induction and maintenance of oestradiol production, response to follicle stimulating hormone and morphological characteristics Biology of Reproduction 56 608-616 
Gutierrez CG, Ralph JH, Telfer EE, Wilmut I and Webb R (2000) Growth and antrum formation of bovine antral follicles in long-term culture in vitro. Biology of Reproduction 62 1322-1328

Louhio H, Hovatta O, Sjoberg J and Tuuri T (2000) The effects of insulin, and insulin-like growth factors I and II on human ovarian follicles in long-term culture Molecular Human Reproduction 6 694-698

McCaffery FH, Leask R, Riley SC and Telfer EE (2000) Culture of bovine preantral follicles in a serum-free system: markers for assessment of growth and development Biology of Reproduction 63 267-273

McCaffery FH, Campbell BK and Telfer EE (2001) Effect of IGF-I on the development of bovine preantral follicles Biology of Reproduction 64 Supplement 1 Abstract 9

Spratt SK, Tatsuno GP and Sommer A (1991) Cloning and characterization of bovine insulin-like growth factor binding protein-3 (IGFBP-3) Biochemical and Biophysical Research Communications 177 1025-1032

van Wezel IL and Rodgers RJ (1996) Morphological characterization of bovine follicles and their environment in vivo. Biology of Reproduction 55 1003-1011

Wandji SA, Srsen V, Voss AK, Eppig JJ and Fortune JE (1996) Initiation in vitro of growth of bovine primordial follicles Biology of Reproduction 55 942-948

Wandji SA, Gadsby JE, Simmen FA, Barber JA and Hammond JM (2000) Porcine ovarian cells express messenger ribonucleic acid for the acidlabile subunit and insulin-like growth factor binding protein-3 during follicular and luteal phases of the estrous cycle Endocrinology 141 2638-2647
Webb R, Campbell BK, Garverick HA, Gong JG, Gutierrez CG and Armstrong DG (1999) Molecular mechanisms regulating follicular recruitment and selection Journal of Reproduction and Fertility Supplement 54 33-48

Woad KJ (2001) The Insulin-like Growth Factor System in the Bovine Corpus Luteum PhD Thesis, University of Edinburgh

Woad KJ, Baxter G, Hogg CO, Bramley TA, Webb R and Armstrong DG (2000) Expression of mRNA encoding insulin-like growth factors I and II and type 1 IGF receptor in the bovine corpus luteum at defined stages of the oestrous cycle Journal of Reproduction and Fertility $\mathbf{1 2 0}$ 293-302

Zhao J, Tavene MAM, Van der Weijden GC, Bevers MM and Van Den Hurk R (2001) Insulin-like growth factor-I (IGF-I) stimulates the development of cultured rat pre-antral follicles Molecular Reproduction and Development $\mathbf{5 8}$ 287-296

Zhou J, Kumar TR, Matzuk MM and Bondy C (1997) Insulin-like growth factor I regulates gonadotropin responsiveness in the murine ovary Molecular Endocrinology 11 1924-1933

Received 29 August 2001.

First decision 8 October 2001.

Revised manuscript received 23 January 2002.

Accepted 11 February 2002. 